\title{
KEBOLEHPERCAYAAN DAN KORELASI ELEMEN MULTIMEDIA DAN ANTARA MUKA TABLET DALAM MENILAI PENCERITAAN DIGITAL
}

\section{(RELIABILITY AND CORRELATION OF MULTIMEDIA ELEMENT AND TABLET INTERFACE IN DIGITAL STORYTELLING)}

\author{
Hashiroh Hussain $^{1} *$ and Norshuhada Shiratuddin ${ }^{2}$ \\ ${ }^{1}$ Institut Pendidikan Guru (IPG), Kampus Sultan Abdul Halim, \\ 08000 Sungai Petani, Kedah, Malaysia \\ ${ }^{2}$ College of Art and Sciences, Universiti Utara Malaysia, \\ 06010 UUM Sintok, Kedah, Malaysia \\ *Corresponding author: hashiroh@ipsah.edu.my
}

Published date: 20 January 2017

To cite this article: Hashiroh Hussain \& Norshuhada Shiratuddin. (2016). Kebolehpercayaan dan korelasi elemen multimedia dan antara muka tablet dalam menilai penceritaan digital. Asia Pacific Journal of Educators and Education, 31, 27-45. http://dx.doi.org/10.21315/apjee2016.31.3

To link to this article: http://dx.doi.org/10.21315/apjee2016.31.3

\begin{abstract}
Abstrak: Penceritaan adalah satu kaedah pengajaran yang berkesan di kalangan pendidik kerana ia lebih mudah dan cepat dilaksanakan. Peralihan kaedah bercerita secara tradisional kepada digital atau lebih dikenali dengan Penceritaan Digital (PD), adalah bersesuaian era teknologi digital masa kini. Suntikan elemen multimedia dalam PD telah memberikan inovasi dalam proses pembelajaran dengan sokongan ciri interaksi teknologi mudah alih. Ciri interaksi semula jadi pada peranti mudah alih seperti skrin sentuh memudahkan interaksi pengguna dengan elemen multimedia seperti teks dan imej bagi menghasilkan penceritaan. Walau bagaimanapun, terdapat kekurangan elemen yang bersesuaian untuk menilai penceritaan dengan teknologi mudah alih. Oleh itu, cadangan kajian ini adalah untuk menggunakan instrumen yang diadaptasikan daripada heuristik (set prinsip keboleh gunaan) yang telah disahkan oleh pakar. Instrumen merupakan soal selidik yang terdiri daripada tiga dimensi yang mewakili pemboleh ubah iaitu: Antara muka tablet, PD dan multimedia. Sampel kajian terdiri daripada 41 responden di salah sebuah Insititut Pendidikan Guru (IPG) dengan menggunakan pensampelan bertujuan. Tujuan utama kajian ini adalah untuk menentukan hubungan antara ketiga-tiga pemboleh ubah utama dalam kajian ini sebagai elemen untuk menilai penceritaan dengan interaksi tablet. Bagi menentukan hubungan antara ketiga-tiga pemboleh ubah tersebut, data telah
\end{abstract}


dianalisis dengan Ujian Korelasi Pearson. Dapatan kajian menunjukkan bahawa instrumen mempunyai kebolehpercayaan yang tinggi dan hubungan signifikan yang positif antara semua pemboleh ubah dalam menilai penceritaan menggunakan tablet.

Kata Kunci: antara muka tablet, heuristik, multimedia, penceritaan digital, teknologi mudah alih

\begin{abstract}
Storytelling is an effective teaching method for educators due to its easy and fast implementation. The transition of this method into digital form or better known as Digital Storytelling (DST), is in line with the era of digital technology. The infusion of Multimedia element in storytelling has innovated the learning process with the support of the mobile technology's interaction. Features on Natural User Interface (NUI) in the mobile devices namely as touch screen, facilitates user interaction with the multimedia elements such as text and images. However, there is a lack of appropriate elements to evaluate story on mobile technology. Therefore, this study attempts to propose instrument which adopted from the heuristic (usability principles), which are validated by experts. The instrument is a set of questionnaire comprised of three dimensions (i.e variables): Tablet Interface, Digital Storytelling and Multimedia. Sample study consists of 41 respondents from the Institute of Teacher Education (ITE), using purposive sampling. The aim of this study is to determine the relationship between the variables which are elements to evaluate story on tablet interface. In order to determine the relationship between those variables, the data are analysed with Pearson Correlation Test. Findings indicate that the instrument has high reliability and significant positive relationship among all variables in the evaluation of storytelling on tablet interface.
\end{abstract}

Keywords: tablet interface, heuristic, multimedia, digital storytelling, mobile device

\title{
PENGENALAN
}

Kaedah penyampaian maklumat kepada audiens dapat dilakukan dengan pelbagai cara sama ada secara lisan, skrip cerita, kartun dan filem. Kaedah penceritaan merupakan salah satu kaedah pengajaran popular yang digunakan di kalangan pendidik selain dari teknik pemerhatian, demonstrasi dan lakonan. Ia juga merupakan kaedah yang mudah dan cepat untuk menyampaikan maklumat dan menggalakkan penglibatan murid dalam proses pengajaran dan pembelajaran (Norly, Nadia Akma, Norasikin, \& Nor Zuhaidah, 2013). Peralihan kaedah penceritaan secara tradisional kepada digital atau lebih dikenali dengan Penceritaan Digital (PD), adalah bersesuaian era teknologi digital masa kini. Transformasi kaedah yang inovatif dan kreatif ini membantu menggabungjalinkan tugas seorang pendidik dengan berkesan (Sadik, 2008). Proses penyampaian maklumat telah dapat meningkatkan ingatan dan komunikasi dengan pelajar melalui kaedah pembentangan yang melibatkan penerokaan maklumat dan pengembangan pengetahuan pelajar (Bongshin, Rubaiat, \& Smith, 
2013; Robiatul A'dawiah \& Halimah, 2011). Ohler (2008) juga bersetuju bahawa kombinasi penceritaan dengan teknologi multimedia telah dapat memenuhi kepuasan komunikasi melalui kaedah penceritaan. Selain itu, interaksi dengan pelajar dapat ditingkatkan melalui konsep PD yang telah menghubungkan audiens melalui media dan teknologi (Miller, 2008). Penyaluran maklumat menjadi lebih telus apabila manusia, teknologi dan media, masing-masing mengambil peranan berinteraksi secara langsung antara satu sama lain. Dengan itu, pengenalan PD dalam bidang pendidikan dapat membantu penyampaian maklumat dalam masa yang singkat dan meningkatkan kemahiran teknologi ( $\mathrm{Li}$ $\&$ Chen, 2010; Meadows, 2003).

Seterusnya, perbincangan akan dilanjutkan berkaitan teknologi mudah alih yang digunakan dalam menyampaikan maklumat menggunakan kaedah penceritaan. Seterusnya, elemen yang digunakan untuk menilai penceritaan iaitu PD, multimedia dan antara muka tablet. Proses mengumpul data yang melibatkan beberapa fasa pula dibincangkan dalam seksyen metodologi kajian dan kemudian barulah dapatan analisis kajian akan dibincangkan dalam seksyen berikutnya. Seksyen terakhir akan memberi kesimpulan dapatan kajian dan cadangan masa depan.

\section{Teknologi Mudah Alih}

Perkembangan peralatan teknologi yang semakin canggih dan mudah alih telah menyokong proses perkongsian penceritaan dilakukan dengan lancar. Perkongsian maklumat dalam bentuk cerita ini dapat direalisasikan dengan sokongan peranti mudah alih seperti tablet dan telefon pintar yang membolehkan pembelajaran berlaku di mana-mana. Robin (2014) dan Tackvic (2012) bersetuju penggunaan peralatan komputer dalam proses penceritaan adalah sebagai penambahbaikan yang positif dalam kaedah penceritaan tradisional. Penerimaan positif terhadap peranti mudah alih seperti komputer riba, telefon pintar, tablet juga mendapat sambutan hangat di kalangan penduduk di Malaysia (Xiung, 2013). Ini adalah berikutan dengan penawaran ciri unik yang menyokong interaksi seperti teknologi skrin sentuh (Druin, Bederson, \& Quinn, 2009). Manakala penerimaannya adalah semakin meningkat dalam bidang pendidikan khususnya di institusi pengajian tinggi apabila pakar pendidikan juga telah meramalkan bahawa tablet merupakan peranti mudah alih yang popular dalam tempoh tahun 2011 hingga 2015 (Saedah, Muhammad Helmi, Fadzilah, \& Zaharah, 2010).

Pemilihan tablet sebagai peranti mudah alih yang digunakan dalam kajian ini berbanding dengan peranti mudah alih yang lain adalah kerana dari aspek (i) mudah alih berbanding dengan komputer meja, (ii) saiz skrin lebih besar 
(contohnya, 10 inci untuk iPad) berbanding dengan telefon pintar dan (iii) mempunyai permulaan yang pantas serta wayarles yang sesuai untuk aplikasi media berbanding dengan komputer riba. Di samping itu, penerimaan positif terhadap penggunaan tablet dalam kelas telah menunjukkan peningkatan prestasi pembelajaran pelajar iaitu (i) fokus pelajar meningkat dan mereka memberi perhatian yang penuh dalam kelas, (ii) guru memberi maklum balas yang segera apabila pelajar tidak faham, (iii) guru boleh mengubah bahan pembelajaran serta merta dan (iv) memberikan tahap kepuasan yang tinggi untuk pelajar (Koile \& Singer, 2006). Dengan itu, penggunaan tablet skrin sentuh telah menjadikan pembelajaran menjadi lebih interaktif dan menarik.

Tablet skrin sentuh juga telah memudahkan interaksi pengguna dengan elemen multimedia seperti teks dan imej. Kajian menunjukkan interaksi dengan maklumat di skrin dengan menggunakan jari sebagai peranti input dapat memberi keyakinan pengguna untuk mengawal interaksi mereka (Yao, Fernando, \& Wang, 2012). Ini adalah kerana peranan peranti kawalan input seperti papan kekunci dan tetikus yang telah diambil alih oleh skrin sentuh telah memudahkan input data. Di samping itu, fungsi skrin sentuh seperti membesarkan, mengecilkan dan memindah imej ke lokasi yang dikehendaki melalui input jari telah memudahkan tugasan disiapkan dengan cepat dan mengurangkan kesalahan (Jennings, Ryser, \& Drews, 2013). Di samping itu, proses suntingan media dapat dijimatkan untuk mengubah saiz dan meningkatkan kualiti imej (Sutherland \& Maiden, 2010). Pengguna juga bebas untuk berinteraksi dengan tablet dan interaksi berasaskan imej yang menyeronokkan telah membawa kepada reka bentuk produk yang kreatif dan inovatif yang menepati konsep PD (Liu, 2010; Norman \& Nielsen, 2010).

Untuk merealisasikan penerapan konsep PD dengan lebih berkesan, keperluan kemudahan alatan penceritaan yang bersesuaian adalah diharapkan dapat membantu menjayakan perlaksanaan kajian ini. Penggunaan alatan penceritaan dalam pembinaan produk multimedia adalah penting bagi menentukan bahan media yang dihasilkan adalah menepati konsep PD. Wilkstrom (2013) mendakwa alatan penceritaan dapat menjelaskan penceritaan dan memberi inspirasi kepada idea-idea baru kepada perkembangan suatu cerita. Ia juga dapat membantu menyampaikan maksud cerita dan mengembangkan pemikiran untuk membina penceritaan (Green, 2011). Oleh itu, pelbagai kemahiran teknologi perlu dikuasai oleh guru untuk memberi kefahaman penceritaan kepada pelajar dalam proses menyampaikan maklumat (Sadik, 2008). Penggunaan alatan penceritaan yang biasa digunakan oleh guru adalah seperti Movie Maker, Microsoft PowerPoint dan Prezi kerana ia mudah digunakan, sudah dipasang dan dimuat turun ke dalam komputer. Namun, alatan ini tidak menyokong proses penceritaan (Truong, Hayes, \& Abowd, 2006) dan tidak direka bentuk berdasarkan pendidikan (Rami \& Davies, 2012). Malah, alatan penceritaan lebih berasaskan hiburan dan tidak 
boleh beroperasi dengan peranti mudah alih (Rubegni, Colombo, \& Landoni, 2013). Ini adalah berpunca akibat kekurangan elemen yang bersesuaian untuk menilai proses penceritaan dengan teknologi mudah alih (Kosara \& MacKinlay, 2013). Justeru itu, sebagaimana isu yang telah dibincangkan sebelum ini, maka cadangan kajian adalah untuk memasukkan elemen seperti multimedia dan antara muka tablet untuk menilai PD. Tujuan utama kajian adalah untuk menentukan hubungan antara ketiga-tiga pemboleh ubah utama iaitu antara muka tablet, multimedia dan PD dalam menilai penceritaan. Penilaian adalah bersandarkan dengan heuristik yang sedia ada yang telah disahkan oleh pakar.

\section{Elemen untuk Menilai Penceritaan}

Penilaian penceritaan adalah melibatkan beberapa elemen yang telah dikenal pasti iaitu: antara muka tablet, PD dan multimedia. Setiap elemen mewakili dimensi heuristik yang telah mendapat pengesahan pakar-pakar ulung dalam bidang keboleh gunaan. Heuristik adalah merupakan peraturan umum ibu jari (rules of thumb) atau dikenali sebagai satu set prinsip keboleh gunaan untuk sesuatu produk (Nielsen \& Mack, 1994). Setiap item dalam dimensi heuristik kajian telah mengadaptasikan item heuristik yang sedia ada untuk menilai penceritaan seperti ditunjukkan dalam Jadual 1.

Jadual 1. Dimensi untuk menilai penceritaan

\begin{tabular}{llc}
\hline Dimensi & \multicolumn{1}{c}{ Sumber } & Item \\
\hline Antara muka tablet & Inostroza \& Rusu (2014), Nielsen \& Mack (1994) & 12 \\
Multimedia & Hasiah, Azizah, \& Rohana (2013), Albion (1999) & 8 \\
Penceritaan digital & $\begin{array}{l}\text { Tenh, Norshuhada, \& Harryizman (2012) oleh tujuh } \\
\text { pakar Penceritaan Digital }\end{array}$ & 14 \\
\hline Jumlah item & & 34 \\
\hline
\end{tabular}

Item pada dimensi antara muka tablet adalah yang berasaskan 10 heuristik antara muka oleh Nielsen \& Mack (1994). Ia kemudiannya telah diadaptasi oleh Inostroza dan Rusu (2014) untuk menghasilkan 12 heuristik pada interaksi peranti mudah alih. Interaksi skrin sentuh melalui elemen antara muka tablet telah membolehkan interaksi berlaku antara pengguna dengan elemen multimedia yang lain seperti teks, imej dan audio seperti yang ditunjukkan dalam Jadual 2. Manakala, elemen multimedia telah menyumbang untuk interaksi secara interaktif dengan pengguna (Druin et al., 2009). Oleh itu, cadangan item untuk Dimensi Multimedia menggunakan 8 heuristik multimedia oleh Hasiah et al. (2013) yang berpandukan heuristik penilaian bahan multimedia oleh Albion (1999) seperti ditunjukkan dalam Jadual 3. Seterusnya, 14 elemen utama PD yang dicadangkan oleh Tenh et al. (2012) dan telah mendapat pengesahan tujuh orang pakar ulung PD iaitu Robin, Porter, Ohler, Lambert, Sapeter, Paul dan 
Fiebich dan Schafer telah digunakan sebagai item untuk Dimensi PD seperti ditunjukkan dalam Jadual 4.

Jadual 2. Antara muka tablet

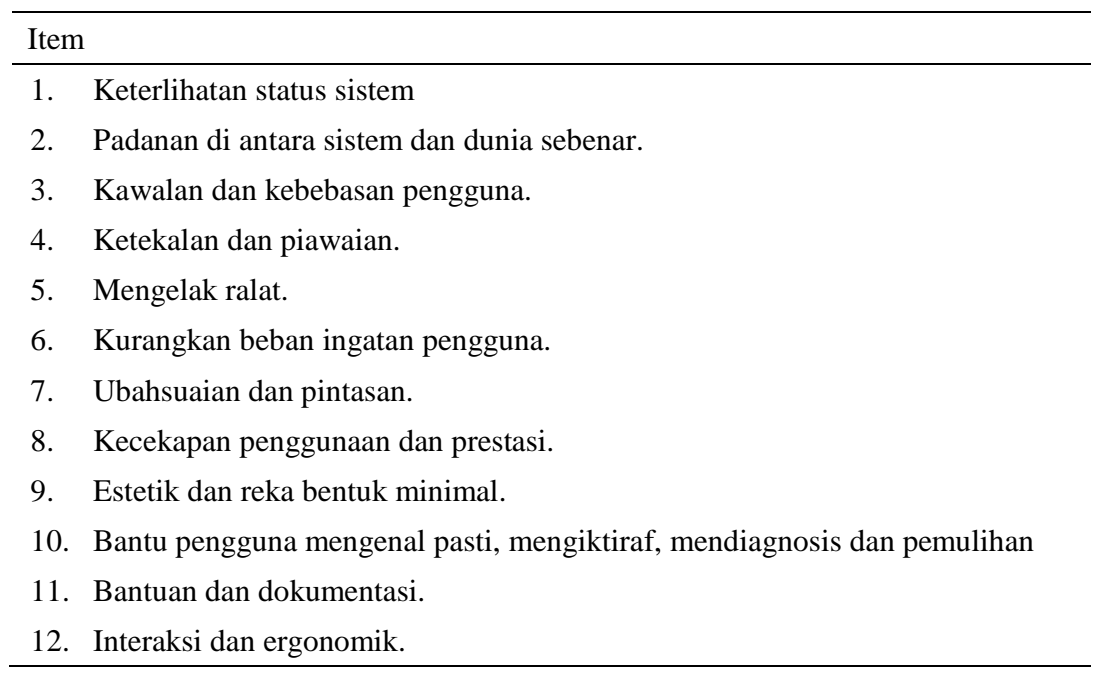

Jadual 3. Multimedia

\begin{tabular}{ll}
\hline Item \\
\hline 1. & Setiap elemen multimedia yang digunakan adalah jelas tujuannya. \\
2. & Penggunaan elemen multimedia adalah bersesuaian dengan isi kandungan \\
3. & Gabungan elemen multimedia adalah bersesuaian. \\
4. & Persembahan elemen multimedia diuruskan dengan baik. \\
5. & Bilangan elemen multimedia untuk sesuatu skrin tidak melebihi dari dua elemen. \\
6. & Penggunaan elemen multimedia yang menarik bagi menyokong maklumat yang diberikan. \\
7. & Kualiti elemen multimedia adalah tinggi. \\
8. & Penggunaan elemen multimedia dapat meningkatkan persembahan kandungan. \\
\hline
\end{tabular}

Jadual 4. Elemen PD

Item

1. Perspektif mengikut pandangan orang yang pertama atau ketiga dalam cerita.

2. Cerita yang dibina bertujuan untuk mencapai objektif suatu tugasan (makluman, pendidikan, hiburan dan lain-lain).

3. Narator menghayati penceritaan, dan memberitahu bagaimana penceritaan mempengaruhi bagi menarik audiens.

4. Persoalan dan situasi digunakan dalam proses penceritaan untuk melibatkan audiens dan penyelesaian akhir. 
Jadual 4. (sambungan)

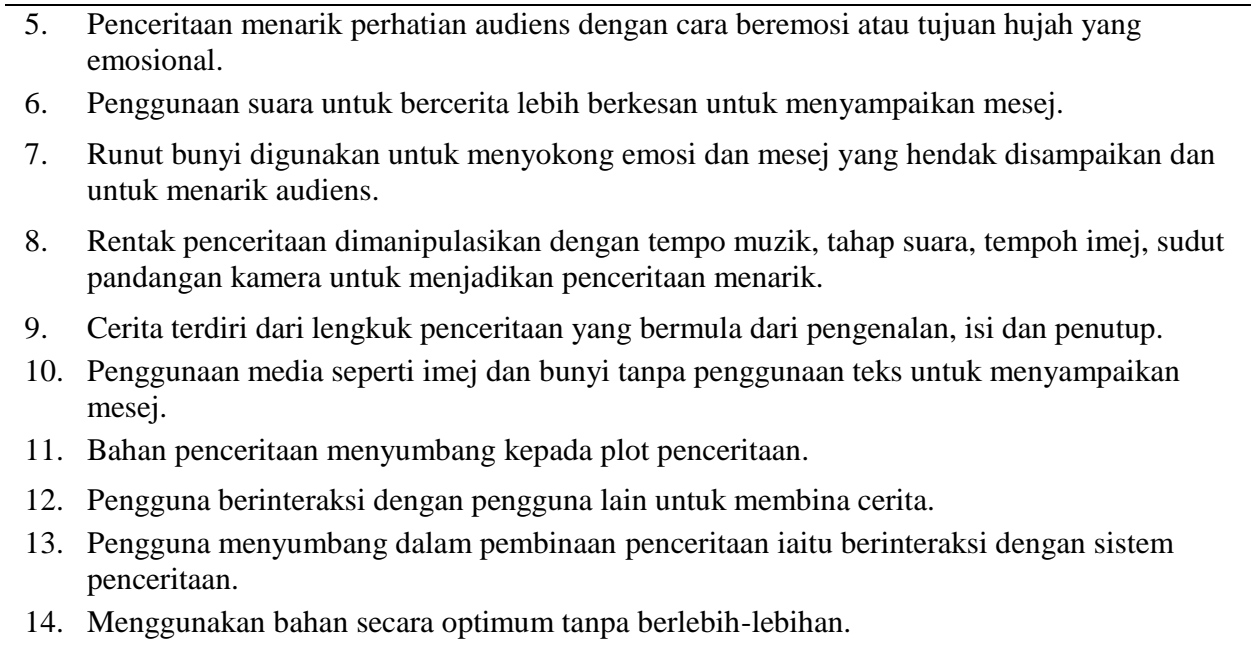

\section{METODOLOGI KAJIAN}

Seksyen ini membincangkan proses pengumpulan data kajian melibatkan beberapa aktiviti yang bermula daripada kajian awal, taklimat ringkas kajian, perlaksanaan tugasan sehinggalah mentadbir instrumen kajian. Ini dapat digambarkan dalam Rajah 1. Satu kajian awal telah dijalankan bagi menentukan pilihan aplikasi PD dengan tablet (iaitu peranti mudah alih dan alatan PD) dalam kalangan pengguna sebelum menjalankan penilaian kajian sebenar. Analisis deskriptif telah digunakan untuk memilih peranti mudah alih yang sesuai digunakan dalam proses menghasilkan penceritaan. Sasaran sampel kajian adalah terdiri daripada warga pendidik di kalangan pelajar (guru pelatih), guru dan pensyarah di Institut Pendidikan Guru (IPG), Kampus Sultan Abdul Halim. Jadual 5 menunjukkan seramai 33 orang responden yang terdiri daripada 18 orang perempuan dan selebihnya 15 orang lelaki. Manakala komposisi pendidik adalah terdiri daripada $30.3 \%$ pensyarah, $48.5 \%$ adalah pelajar Program Ijazah Sarjana Muda Perguruan (PISMP) dan $21.2 \%$ adalah guru dalam perkhidmatan daripada Program Pensiswazahan Guru (PPG). Dapatan kajian menunjukkan $58 \%$ responden bersetuju bahawa tablet menjadi pilihan untuk tujuan pembelajaran seperti yang digambarkan dalam Rajah 2. 


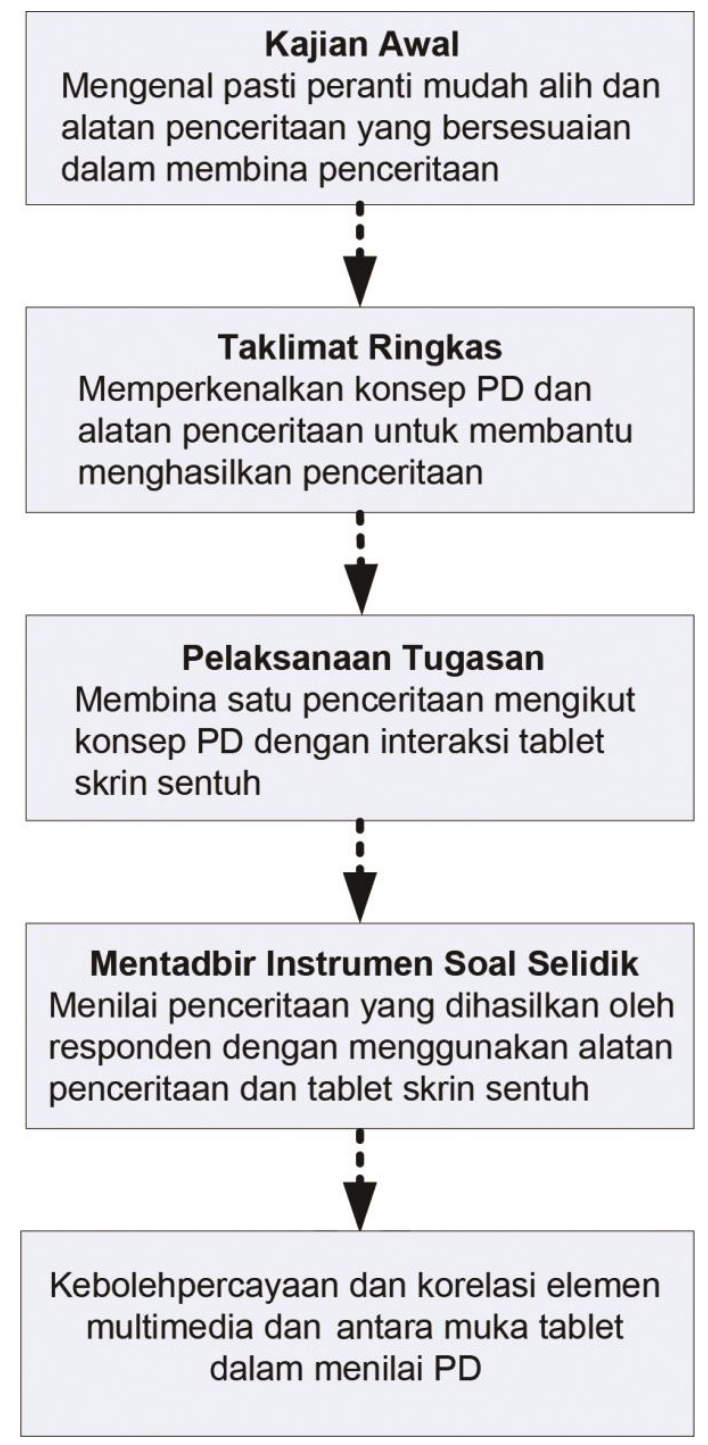

Rajah 1. Aktiviti pengumpulan data kajian 


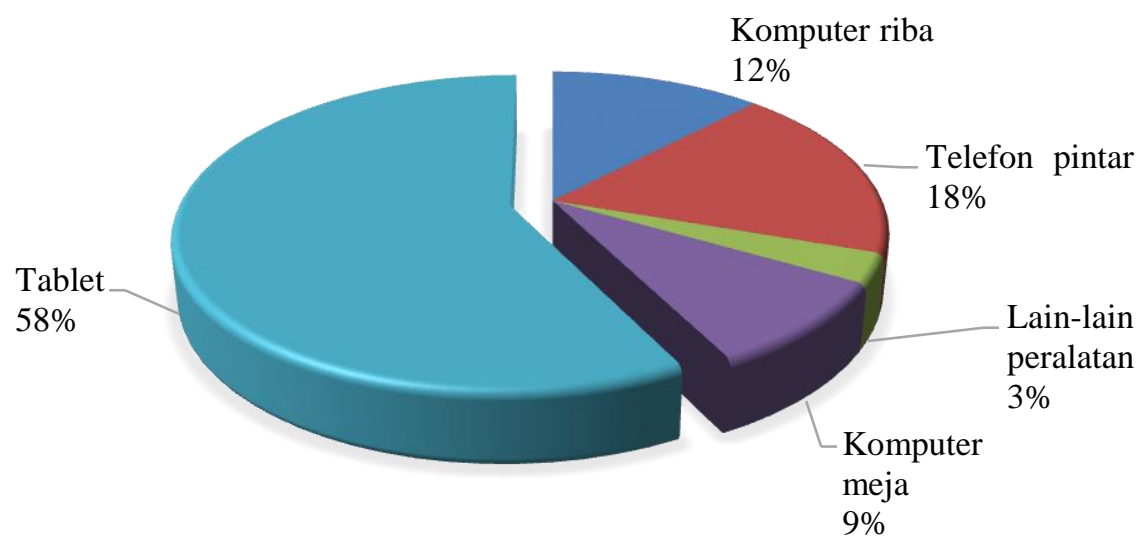

Rajah 2. Pilihan peranti mudah alih

Jadual 5. Demografi responden

\begin{tabular}{ccccccc}
\hline \multirow{2}{*}{ Demografi } & \multicolumn{3}{c}{ Jantina } & \multirow{2}{*}{ Jumlah } & Peratus (\%) \\
\cline { 3 - 4 } \multicolumn{2}{c}{ Bangsa } & Melayu & 10 & 11 & 21 & 63.6 \\
& Cina & 1 & 5 & 6 & 18.2 \\
& Lain-lain & 4 & 2 & 6 & 18.2 \\
\hline Jumlah & & 15 & 18 & 33 & \\
\hline Pendidik & Pensyarah & 7 & 3 & 10 & 30.3 \\
& PISMP & 7 & 9 & 16 & 48.5 \\
& PPG & 1 & 6 & 7 & 21.2 \\
\hline Jumlah & & 15 & 18 & 33 & \\
\hline
\end{tabular}

Seterusnya, analisis perbandingan pula digunakan untuk memilih alatan PD yang bersesuaian untuk membantu menghasilkan penceritaan. Jadual 6 menunjukkan perbandingan daripada beberapa alatan penceritaan yang sedia ada iaitu Storykit, Photostory, Storyboardthat dan Scratch yang boleh berfungsi dengan tablet. Hasil analisis tersebut telah mencadangkan Storykit yang mempunyai skor yang tertinggi sebagai alatan penceritaan dengan fungsian fitur yang berikut: kos percuma, boleh mengambil gambar dari kamera dan merakam audio, membenarkan suntingan elemen multimedia dengan mudah, perkongsian data dari server, eksport bahan dalam bentuk digital (softcopy) dan beroperasi dengan tablet. Antara muka Storykit adalah seperti yang diilustrasikan dalam Rajah 3. 


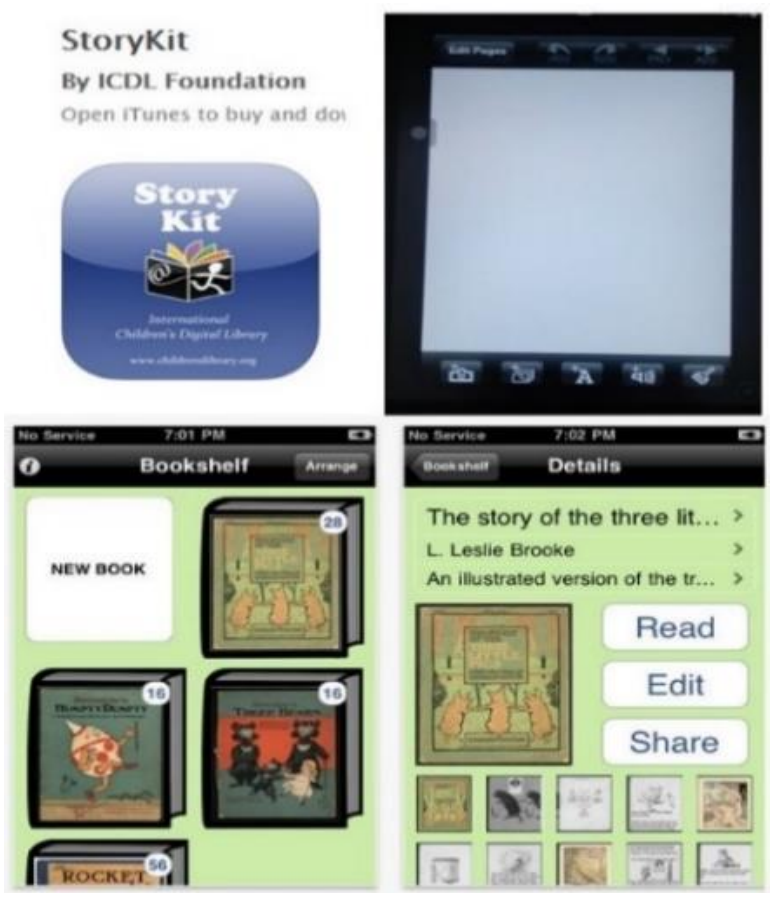

Rajah 3. Antara muka Storykit

Jadual 6. Analisis perbandingan fungsian antara tiga alatan penceritaan mudah alih

\begin{tabular}{lcccc}
\hline Fungsian fitur & Storykit & Photostory & Storyboardthat & Scratch \\
\hline Melukis & $\mathrm{X}$ & $\mathrm{X}$ & $\mathrm{X}$ & $\mathrm{TD}$ \\
Guna imej dari pustaka & $\mathrm{X}$ & $\mathrm{X}$ & $\mathrm{X}$ & $\mathrm{X}$ \\
Ambil dan sunting gambar & $\mathrm{X}$ & $\mathrm{X}$ & $\mathrm{X}$ & $\mathrm{X}$ \\
Guna video dari pustaka & $\mathrm{X}$ & $\mathrm{X}$ & $\mathrm{TD}$ & $\mathrm{X}$ \\
Rakam dan sunting video & $\mathrm{X}$ & $\mathrm{X}$ & $\mathrm{TD}$ & $\mathrm{X}$ \\
Guna audio dari pustaka & $\mathrm{X}$ & $\mathrm{X}$ & $\mathrm{X}($ dibeli) & $\mathrm{X}$ \\
Rakam and sunting audio & $\mathrm{X}$ & $\mathrm{X}$ & $\mathrm{X}($ dibeli) & $\mathrm{X}$ \\
Taip dan sunting teks & $\mathrm{X}$ & $\mathrm{X}$ & $\mathrm{X}$ & $\mathrm{X}$ \\
Kongsi data dari pelayan & $\mathrm{X}$ & $\mathrm{X}$ & $\mathrm{X}$ & $\mathrm{X}$ \\
Slot untuk adegan & $\mathrm{X}$ & $\mathrm{TD}$ & $\mathrm{X}$ & $\mathrm{TD}$ \\
Ekspot ke bentuk digital & $\mathrm{X}$ & $\mathrm{X}$ & $\mathrm{X}$ & $\mathrm{X}$ \\
Beroperasi dengan tablet & $\mathrm{X}$ & $\mathrm{VB}$ & $\mathrm{X}$ & $\mathrm{X}$ \\
Percuma & $\mathrm{X}$ & $\mathrm{X}$ & $\mathrm{TD}$ & $\mathrm{TD}$ \\
Jumlah Skor & 13 & 11 & 8 & 10 \\
\hline
\end{tabular}

TD: Tidak Disediakan; VB: Versi Cubaan 
Satu taklimat ringkas telah diadakan kepada responden untuk memperkenalkan konsep PD dan alatan Penceritaan Digital seperti digambarkan dalam Rajah 4. Seramai 41 orang pelajar Semester 4 PISMP daripada IPG Kampus Sultan Abdul Halim, Kedah telah mengambil bahagian sebagai responden kajian. Kajian ini melibatkan sesi kelas pelajar yang mengambil kursus teras/wajib iaitu Teknologi Pengajaran dan Pembelajaran (EDU3105) di IPG. Responden telah diberi tugasan berdasarkan projek pembinaan produk multimedia sebagai bahan penceritaan. Hasil pemerhatian menunjukkan pengenalan alatan penceritaan, Storykit telah menarik minat responden kerana antara muka Storykit yang menyerupai buku dengan fitur utama iaitu New Book, Read, Edit dan Share telah memudahkan proses menghasilkan penceritaan. Mereka teruja untuk menggunakan alatan yang baru kerana interaksi antara mukanya yang mesra pengguna.

Pelaksanaan tugasan membina penceritaan dalam bentuk produk multimedia telah dijalankan oleh responden dengan bantuan alatan penceritaan, Storykit. Mereka juga tidak mempunyai masalah menggunakannya kerana mempunyai pengalaman asas pembinaan produk multimedia semenjak Semester 1. Tugasan khusus yang diberikan adalah untuk membina satu papan cerita sebagai perancangan untuk menghasilkan produk multimedia yang berkonsepkan PD dengan menggunakan Storykit. Proses pembinaan dilakukan dalam kumpulan bagi mempercepatkan proses menghasilkan penceritaan dengan tablet dalam tempoh yang singkat (iaitu kurang daripada 1 jam) tetapi mempunyai isi kandungan cerita yang padat. Situasi ini dapat digambarkan dalam Rajah 5.

Seterusnya, bagi menilai penceritaan yang telah dihasilkan oleh responden, satu set instrumen soal selidik telah ditadbir. Soal selidik tersebut terbahagi kepada dua seksyen: latar belakang responden dan heuristik penceritaan yang terdiri daripada tiga dimensi iaitu antara muka tablet, multimedia dan PD (seperti yang ditunjukkan di dalam Jadual 2 hingga 4). Soal selidik kajian ini menggunakan pengukuran skala Likert berdasarkan 7 skala mata dengan tujuh pilihan seperti ditunjukkan dalam Jadual 7.

Jadual 7. Skala Likert kajian

\begin{tabular}{cl}
\hline Skala & \multicolumn{1}{c}{ Pilihan } \\
\hline 1 & Amat sangat tidak penting \\
2 & Sangat tidak penting \\
3 & Tidak penting \\
4 & Kurang penting \\
5 & Penting \\
6 & Sangat penting \\
7 & Amat sangat penting \\
\hline
\end{tabular}




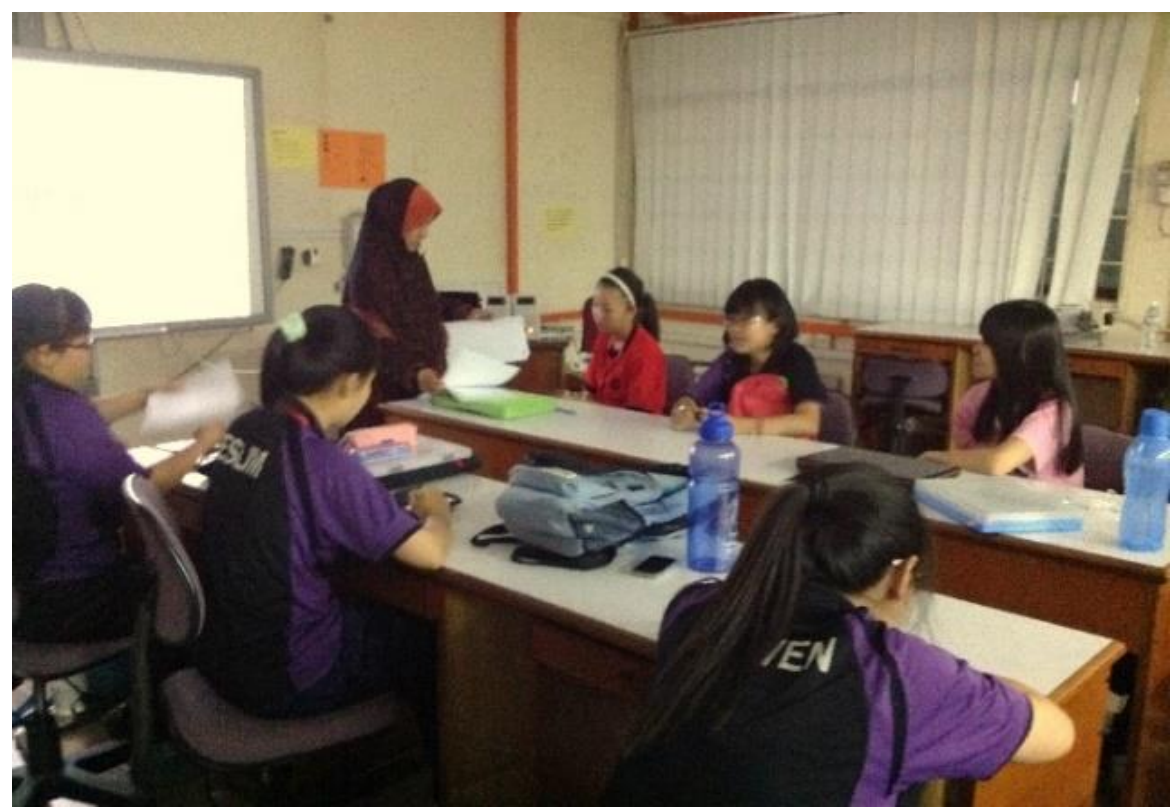

Rajah 4. Penyelidik memberikan taklimat ringkas kepada responden

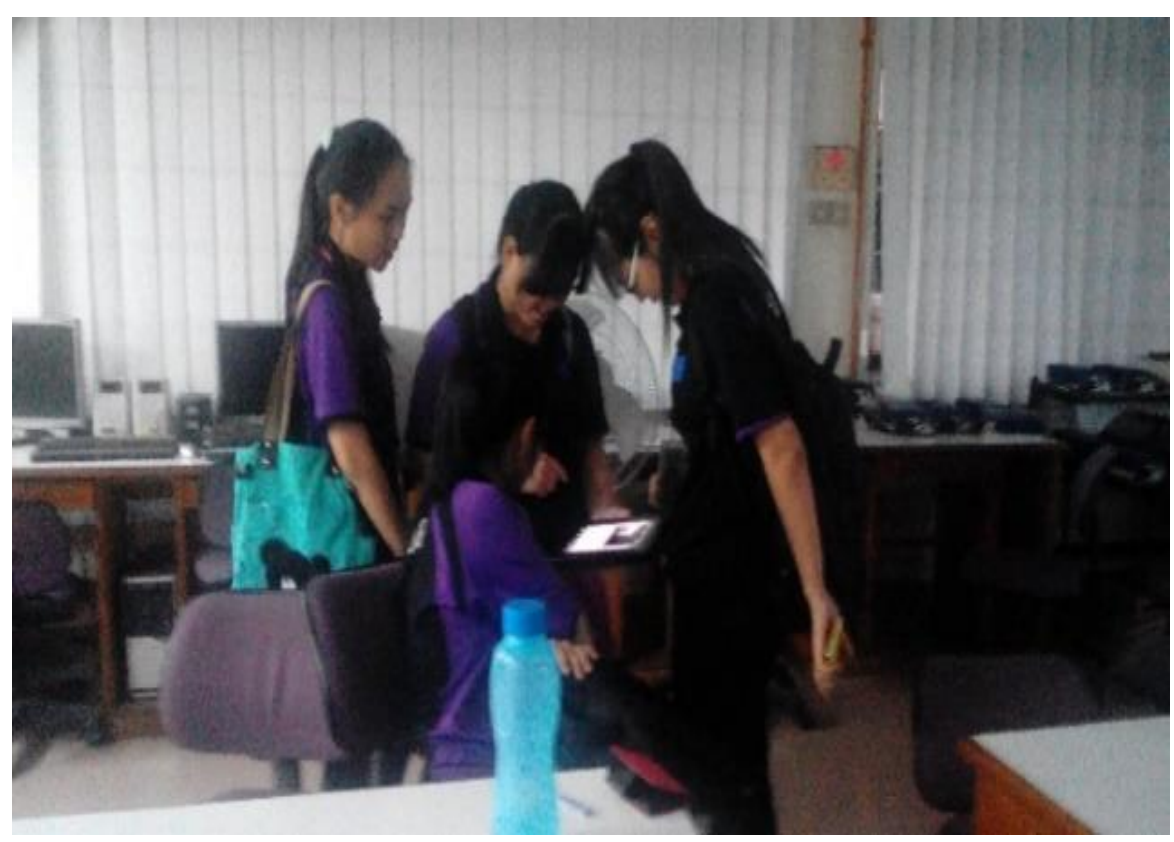

Rajah 5. Responden dibahagikan ikut kumpulan tugasan dengan Storykit 
Instrumen soal selidik telah diuji melalui analisis kesahan dan analisis kebolehpercayaan sebelum analisis kajian sebenar dijalankan. Kesahan instrumen yang mengandungi item-item heuristik telah dilakukan oleh pakar mengikut bidang seperti antara muka, PD dan multimedia. Kemudian, kebolehpercayaan item instrumen kajian ditentukan dengan pekali Cronbach Alpha. Menurut George dan Mallery (2001) bagi sesuatu instrumen yang mempunyai kebolehpercayaan, aras pekali/nilai Cronbach Alpha mestilah sekurangkurangnya 0.7. Nilai Alpha kurang daripada 0.60 dianggap rendah dan tidak diterima, manakala nilai Alpha antara 0.60 hingga 0.80 adalah diterima (Mohd Majid, 2000; Sekaran, 1992). Analisis kebolehpercayaan yang diperolehi terhadap 34 item dalam instrumen kajian ini telah memperolehi purata nilai Alpha yang tinggi iaitu 0.883 . Nilai ini adalah melebihi 0.80 yang menunjukkan item tersebut mempunyai kebolehpercayaan yang tinggi untuk meneruskan analisis sebenar terhadap instrumen ini.

\section{DAPATAN DAN PERBINCANGAN}

Seksyen ini membincangkan dapatan analisis kajian yang dijalankan untuk menilai penceritaan yang dihasilkan oleh responden dengan bantuan alatan penceritaan dengan tablet skrin sentuh. Perbincangan ini bertujuan untuk mengetengahkan penemuan hasil maklum balas responden. Profil demografi responden yang telah mengambil bahagian dalam kajian ini adalah seperti yang ditunjukkan dalam Jadual 8. Seramai 41 orang responden yang terlibat dalam kajian ini telah dipilih mengikut pensampelan bertujuan. Mereka terdiri daripada $80.5 \%$ responden perempuan dan bakinya $19.5 \%$ responden lelaki. Bagi komposisi bangsa, majoriti terdiri daripada responden Cina (63.4\%), Melayu $(26.8 \%)$ dan selebihnya bangsa lain $(9.8 \%)$.

Jadual 8. Profil demografi responden

\begin{tabular}{ccccc}
\hline Bangsa & Lelaki & Perempuan & Frekuensi & Peratus (\%) \\
\hline Melayu & 5 & 6 & 11 & 26.8 \\
Cina & 2 & 24 & 26 & 63.4 \\
Lain-lain & 1 & 3 & 4 & 9.8 \\
\hline Jumlah & $8(19.5 \%)$ & $33(80.5 \%)$ & 41 & 100.0 \\
\hline
\end{tabular}

Seterusnya, analisis deskriptif yang melibatkan nilai min, skor dan sisihan piawai telah digunakan untuk melihat taburan item mengikut dimensi seperti ditunjukkan dalam Jadual 9. Sebanyak tiga dimensi yang terlibat iaitu antara muka tablet, multimedia dan PD. Dimensi pertama adalah antara muka tablet dengan min keseluruhan $=5.78$, dan skor tertinggi adalah 6.56 iaitu item ke 2 
ialah padanan di antara sistem dan dunia sebenar (rujuk Jadual 2). Item ini adalah berkenaan dengan bahasa atau arahan yang jelas digunakan pada alatan penceritaan ini adalah penting. Ini adalah kerana terdapat responden mempunyai latar belakang bukan teknikal yang sukar untuk memahami arahan dan terminologi dengan betul. Dimensi kedua ialah multimedia dengan min keseluruhan $=6.07$ dan skor tertinggi adalah 6.54 iaitu item ke 3 ialah gabungan elemen multimedia adalah bersesuaian (rujuk Jadual 3). Seperti yang dijangkakan elemen multimedia merupakan penyumbang utama dalam menyampaikan maklumat dalam PD. Ini adalah kerana melalui gabungan teks, imej dan audio dalam suatu persembahan penceritaan penting untuk menjadikan ia lebih interaktif dan menarik. Dimensi yang terakhir adalah PD dengan min keseluruhan adalah 6.11 dan skor tertinggi adalah 6.39 iaitu item ke 5 ialah Penceritaan menarik perhatian audiens dengan cara beremosi atau tujuan hujah yang emosional (rujuk Jadual 4). Suatu cerita akan menjadi lebih menarik dan jika berupaya mengekalkan minat pelajar secara beremosi untuk mendengar cerita yang disampaikan.

Jadual 9. Skor min dan sisihan piawai untuk setiap dimensi

\begin{tabular}{ccccccc}
\hline \multirow{2}{*}{ Bil } & \multicolumn{2}{c}{ Antara muka tablet } & \multicolumn{2}{c}{ Multimedia } & \multicolumn{2}{c}{ Penceritaan Digital } \\
\cline { 2 - 7 } & Min & Sisihan piawai & Min & Sisihan piawai & Min & Sisihan piawai \\
\hline 1 & 5.71 & 1.123 & 6.15 & 0.792 & 5.95 & 0.973 \\
2 & $\mathbf{6 . 5 6}$ & 0.673 & 6.22 & 0.881 & 6.15 & 0.792 \\
3 & 5.83 & 1.138 & $\mathbf{6 . 5 4}$ & 0.596 & 6.02 & 0.908 \\
4 & 5.71 & 0.844 & 5.88 & 0.872 & 6.00 & 0.806 \\
5 & 5.32 & 1.491 & 5.24 & 1.280 & $\mathbf{6 . 3 9}$ & 0.703 \\
6 & 5.39 & 1.222 & 5.85 & 0.963 & 6.22 & 0.852 \\
7 & 5.49 & 1.165 & 6.20 & 0.813 & 6.22 & 0.852 \\
8 & 5.63 & 1.220 & 6.51 & 0.779 & 5.83 & 0.972 \\
9 & 5.63 & 1.199 & & & 6.24 & 0.888 \\
10 & 6.17 & 1.022 & & & 5.90 & 0.800 \\
11 & 5.83 & 0.946 & & & 6.17 & 0.892 \\
12 & 6.15 & 0.882 & & & 6.12 & 1.053 \\
13 & & & & & 6.02 & 0.724 \\
14 & & & & & 6.32 & 0.907 \\
\hline Purata & 5.78 & 0.923 & 6.07 & & 6.11 & 0.866 \\
\hline
\end{tabular}

Secara keseluruhannya, berpandukan Jadual Skala Likert (rujuk Jadual 7), purata min bagi semua dimensi adalah melebihi skala 5 iaitu Penting khususnya purata min yang tertinggi untuk PD pada skala melebihi 6 (Sangat Penting) bagi menguatkan kepentingan elemen PD dalam hasil penceritaan. Di samping itu, 
nilai sisihan piawai adalah kurang daripada 1 bagi semua dimensi (antara muka tablet $=0.923$, multimedia $=0.498$ dan $\mathrm{PD}=0.866$ ) menunjukkan semakin kecil sisihan piawai, semakin kecil sebaran skor dalam taburan yang membawa implikasi bahawa data adalah berhampiran antara satu sama lain (homogen). Taburan data yang homogen ini membuktikan keboleh kepercayaaan yang tinggi bagi instrumen tersebut (Creswell, 2014).

Seterusnya, analisis Korelasi Pearson telah digunakan untuk menentukan sama ada terdapat perkaitan antara tiga pemboleh ubah: antara muka tablet, multimedia dan PD. Hubungan antara tiga pemboleh ubah ini telah diuji dengan mengambil kira kekuatan hubungan yang berpandukan kepada Skala Kekuatan Hubungan oleh Cohen, Manion dan Marrison (2011) seperti ditunjukkan Jadual 10.

Jadual 10. Kekuatan hubungan mengikut nilai pekali korelasi

\begin{tabular}{cc}
\hline Saiz Pekali Korelasi(r $)$ & Kekuatan Korelasi \\
\hline \pm .81 hingga 1.00 & Sangat Kuat \\
\pm .51 hingga .80 & Kuat \\
\pm .31 hingga .50 & Sederhana \\
\pm .21 hingga .30 & Lemah \\
\pm .01 hingga .20 & Sangat lemah \\
\hline
\end{tabular}

Hasil kajian Analisis Inter Korelasi Pearson dalam Jadual 11 menunjukkan terdapat hubungan signifikan antara ketiga-tiga pemboleh ubah dengan nilai signifikan, $p<.05$. Di mana terdapat korelasi yang kuat dan positif antara Penceritaan Digital dan Multimedia dengan nilai signifikan, $p=.000$ dan nilai pekali, $r=0.703$. Perkaitan PD dan multimedia yang mempengaruhi penghasilan penceritaan selaras dengan kajian oleh Tackvic (2012) dan Yahya dan Dayang Raini (2011) yang mendakwa suntikan multimedia memberi impak positif dalam penceritaan. Manakala, terdapat korelasi yang sederhana dan positif antara PD dan antara muka tablet dengan nilai signifikan, $p=.003$ dan nilai pekali, $r=0.424$. Ini membuktikan kesesuaian antara muka tablet dengan elemen Penceritaan Digital yang mempunyai elemen penglibatan dan kolaboratif yang melibatkan interaksi antara pengguna dengan antara muka tablet (Tenh, Norshuhada, \& Harryizman, 2011). Manakala, hubungan dua pemboleh ubah terakhir iaitu multimedia dan antara muka tablet dengan nilai signifikan, $p=.001$ dan nilai pekali, $r=0.495$ yang mempunyai korelasi yang sederhana dan positif. Di mana, kesesuaian antara muka tablet dapat memudahkan interaksi pengguna dengan elemen multimedia seperti teks, imej dan audio. 
Jadual 11. Analisis inter korelasi Pearson

\begin{tabular}{llccc}
\hline \multicolumn{1}{c}{ Dimensi } & Penceritaan & Multimedia & $\begin{array}{c}\text { Antara muka } \\
\text { tablet }\end{array}$ \\
\hline Penceritaan & Pearson Correlation & 1 & $.703^{* *}$ & $.424^{* *}$ \\
Digital & Sig.(1-tailed) & & .000 & .003 \\
& $\mathrm{~N}$ & 41 & 41 & 41 \\
Multimedia & Pearson Correlation & $.703^{* *}$ & 1 & $.495^{* *}$ \\
& Sig.(1-tailed) & .000 & & .001 \\
& $\mathrm{~N}$ & 41 & 41 & 41 \\
Antara muka & Pearson Correlation & $.424^{* *}$ & $.495^{* *}$ & 1 \\
tablet & Sig.(1-tailed) & .003 & .001 & \\
& $\mathrm{~N}$ & 41 & 41 & 41 \\
\hline
\end{tabular}

** Korelasi adalah signifikan pada aras 0.01 (2-tailed).

\section{KESIMPULAN DAN CADANGAN MASA DEPAN}

Kajian yang dijalankan menunjukkan instrumen kajian dengan ketiga-tiga pembolehubah iaitu PD, antara muka tablet dan multimedia adalah bersesuaian untuk menilai penceritaan kerana mempunyai kebolehpercayaan yang tinggi, skor min yang tinggi dan nilai sisihan piawai yang menghampiri 1. Di samping itu, terdapat hubungan yang signifikan dengan magnitud positif antara ketiga-tiga pemboleh ubah tersebut dalam menilai penceritaan pada tablet skrin sentuh. Di mana, setiap pemboleh ubah berkadar terus antara satu sama lain iaitu semakin tinggi PD, semakin tinggi multimedia dan semakin tinggi antara muka tablet. Dengan itu, ini membuktikan bahawa ketiga-tiga pemboleh ubah adalah signifikan sebagai elemen untuk menilai penceritaan dengan sebarang alatan penceritaan yang sesuai. Transformasi penceritaan secara tradisional kepada PD menjadi lebih interaktif melalui penggunaan elemen multimedia yang sesuai berinteraksi dengan antara muka tablet. Kajian ini mencadangkan penggunaan analisis yang lebih dipercayai dan kuat seperti analisis regresi sebagai kajian masa depan untuk menentukan peramal utama dalam konteks penilaian. Di samping itu, populasi dan sampel kajian perlu diperluaskan kepada semua pelajar IPG di Malaysia bagi memudahkan generalisasi dibuat. 


\section{RUJUKAN}

Albion, P. (1999). Heuristic evaluation of educational multimedia: From theory to practice. ASCILITE99 Conference Proceedings, Brisbane, Australia.

Bongshin, L., Rubaiat, H. K., \& Smith, G. (2013). SketchStory: Telling more engaging stories with data through freeform sketching. IEEE Transactions on Visualization and Computer Graphics, 19(12), 2416-2425. http://dx.doi.org/ 10.1109/TVCG.2013.191

Cohen, L., Manion, L., \& Marrison, K. (2011). Research methods in education (7th ed.). New York, USA: Routledge Taylor \& Francis Group.

Creswell, J. W. (2014). Educational research: Planning, conducting and evaluating quantitative and qualitative research (4th ed.). London: Pearson.

Druin, A., Bederson, B. B., \& Quinn, A. (2009). Designing intergenerational mobile storytelling. In Proceedings of the 8th International Conference on Interaction Design and Children (pp. 325-328). ACM.

George, G., \& Mallery, P. (2001). SPSS for windows step by step : A simple guide and reference 11.0 update. Boston MA: Allyn \& Bacon.

Green, M. R. (2011). Teaching the writing process through digital storytelling in pre service education. Unpublished doctoral dissertation, Texas University.

Hasiah, M. O., Azizah, J., \& Rohana, Y. (2013). Usability of educational computer game (UsaECG): A quantitative approach. Pertanika Journal Science \& Technology, 21(1), 247-260.

Inostroza, R., \& Rusu, C. (2014). Mapping usability heuristics and design principles for touchscreen-based mobile devices. In Proceedings of the 7th Euro American Conference on Telematics and Information Systems (p. 27). ACM.

Jennings, A., Ryser, S., \& Drews, F. (2013). Touch screen devices and the effectiveness of user interface methods. In Proceedings of the Human Factors and Ergonomics Society Annual Meeting (Vol. 57, pp. 1648-1652). http://dx.doi.org/ $10.1177 / 1541931213571366$

Koile, K., \& Singer, D. (2006). Improving learning in CS1 via tablet-PC-based in-class assessment. In Proceedings of the 2006 I nternational workshop on Computing education research-ICER'06 (p. 119). New York, USA: ACM Press. http://dx.doi.org/10.1145/1151588.1151607

Kosara, R., \& MacKinlay, J. (2013). Storytelling: The next step for visualization. Computer, 46, 44-50. http://dx.doi.org/10.1109/MC.2013.36

Li, X., \& Chen, H. (2010). The application of digital storytelling in teaching evaluation. In 2010 2nd International Conference on Education Technology and Computer (ICETC) (Vol. 4, pp. 249-252). Shanghai: IEEE Computer Society.

Liu, W. (2010). Natural user interface- next mainstream product user interface. In 2010 IEEE 11th International Conference on Computer-Aided Industrial Design \& Conceptual Design (CAIDCD) (Vol. 1, pp. 203-205). http://dx.doi.org/ 10.1109/CAIDCD.2010.5681374

Meadows, D. (2003). Digital storytelling: Research-based practice in new media. Visual Communication, 2(2), 189-193. http://dx.doi.org/10.1177/1470357203 002002004

Miller, C. H. (2008). Digital storytelling: A creator's guide to interactive entertainment (2nd ed.). Burlington, USA: Focal Express. 
Mohd Majid, K. (2000). Kaedah penyelidikan pendidikan. Kuala Lumpur: Dewan Bahasa dan Pustaka.

Nielsen, J., \& Mack, R. L. (1994). Heuristic evaluation. In Usability inspection methods (pp. 25-62). New York, NY: John Wiley \& Sons.

Norly, J., Nadia Akma, A. Z., Norasikin, F., \& Nor Zuhaidah, M. Z. (2013). Keberkesanan penceritaan digital interaktif kanak-kanak terhadap penglibatan dalam pengajaran dan pembelajaran. In Prosiding Seminar Penyelidikan Pendidikan IPG: International Conference on Early Childhood Education (Vol. 1). Terengganu, Malaysia: IPG Kampus Dato Razali. Retrieved from http://ojs.cakna.net/index.php/spp/article/view/875

Norman, D. A., \& Nielsen, J. (2010). Gestural interfaces :A step backward in usability. Interactions, 17(5), 46-49.

Ohler, J. (2008). Digital storytelling in the classroom new media pathways to literacy, learning, and creativity (2nd ed.). United States of America: SAGE Publications, Inc. Retrieved from http://www.amazon.com/Digital-StorytellingClassroom-Pathways-Creativity/dp/1452268258

Rami, M., \& Davies, P. (2012). Integration of multimedia technologies to facilitate reflection and learning, particularly in the area of digital storytelling. In International Conference on Education and e-Learning Innovations. United Kingdom: IEEE Computer Society.

Robiatul A'dawiah, J., \& Halimah, Z. B. (2011). Pembangunan perisian cerita animasi interaktif untuk pendidikan sains. Jurnal Teknologi Pendidikan Malaysia, 1, 518. Retrieved from http://www.jtpm-meta.com/resources/141-JTPMV1N4-2011Rabiatul-1.pdf

Robin, B. R. (2014). Educational uses of digital storytelling. How to use. The University of Houston, Texas. Retrieved from http://digitalstorytelling.coe.uh.edu/

Rubegni, E., Colombo, L., \& Landoni, M. (2013). Design recommendations for the development of a Digital Storytelling mobile application. In Proceedings of the 27th International BCS Human Computer Interaction Conference (HCI 2013). Retrieved from http://dl.acm.org/citation.cfm?id=2578096

Sadik, A. (2008). Digital storytelling: a meaningful technology-integrated approach for engaged student learning. Educational Technology Research and Development, 56(4), 487-506.

Saedah, S., Muhammad Helmi, N., Fadzilah, S., \& Zaharah, H. (2010). M-learning Curiculum Transformation.Paper presented at International Educational Technology Conference (IETC), 26-28 April, Istanbul, Turkey.

Sekaran, U. (1992). Research methods for business: A skills-building approach. New York: Wiley and Sons.

Sutherland, M., \& Maiden, N. (2010). Storyboarding requirements. IEEE Software, 27(6), 9-11. http://dx.doi.org/10.1109/ms.2010.147

Tackvic, C. (2012). Digital storytelling: Using technology to spark creativity. The Educational Forum, 76(4), 426-429. http://dx.doi.org/10.1080/00131725. 2012.707562

Tenh, H. K., Norshuhada, S., \& Harryizman, H. (2011). Digital storytelling's conceptual model: A proposed guide towards the construction of a digital story. In International Conference on Teaching and Learning in Higher Education (ICTLHE 2011), Melaka. 
Tenh, H. K., Norshuhada, S., \& Harryizman, H. (2012). Core elements of digital storytelling from experts' Perspective. Knowledge Management International Conference (KMICe) 2012, (July), 397-402. Retrieved from http://www.kmice.cms.net.my/ProcKMICe/KMICe2012/ PDF/CR163.pdf

Truong, K. N., Hayes, G. R., \& Abowd, G. D. (2006). Storyboarding: An empirical determination of best practices and effective guidelines. In Proceedings of the 6th conference on Designing Interactive systems (pp. 12-21). New York, NY: ACM New York. http://dx.doi.org/10.1145/1142405.1142410

Wilkstrom, A. (2013). Storyboarding: framing and reframing opputurnities in the front-front end of innovation. School of Innovation, Design, Engineering, Malardalen University, Sweden.

Xiung, C. J. (2013, September 12). Smartphone penetration hits 63 percent in Malaysia. The Star Online. Retrieved from http://www.thestar.com.my/Tech/TechNews/2013/09/12/Smartphone-and-tablet-penetration-hits-63-percent.aspx/

Yahya, O., \& Dayang Raini, P. (2011). Kesan aplikasi perisian cerita interaktif semasa mengajarkan kemahiran bacaan dan kefahaman dalam kalangan murid tahun 4 di Brunei Darussalam. Jurnal Pendidikan Bahasa Melayu, 1(1), 27-49.

Yao, J., Fernando, T., \& Wang, H. (2012). A multi-touch natural user interface framework. In 2012 International Conference on Systems and Informatics (ICSAI) (pp. 499-504). http://dx.doi.org/10.1109/ICSAI.2012.6223046 